\title{
SALGIN HASTALIKLARIN KADIN SAĞLIĞINA YANSIMALARI
}

\section{Öz}

Geçmişten günümüze Dünya tarihine bakıldığında birçok salgın hastalık yer almıştır. Dünya'yı etkileyen ve birçok insanın ölümüne yol açan salgın hastalıklar önemli bir halk sağlı̆̆ problemidir. Bu salgınlardan kara veba, kolera, İspanyol gribi, HIV/AIDS, H1N1, zika virüsü ve Covid-19 en göze çarpan salgın hastalıklar olarak karşımıza çıkmaktadır. Salgın hastalıklar kadınları ve erkekleri farklı şekilde etkilemektedir. Risk grubunda olan kadınlarda özellikle de gebelerde salgın hastalıkların etkisi daha farklı görülmüş ve gelecek nesil üzerinde de olumsuz etkiler bırakabilmiştir. Salgın hastalıklar üreme sağlığı ve cinsel sağlığı da çeşitli şekillerde etkileyebilmektedir. Bunların sonucunda da anne ve yenidoğan ölümlerinde artış, doğum kontrol yöntemi taleplerinin karşılanamaması, cinsel yolla bulaşan hastalıkların ve istemli küretajın artması, abortus, travma sonrası stres bozukluğu, depresyon, intihar ve şiddet görülebilmektedir. Bu sebeple salgın hastalıklarda kadınların ayrı olarak ele alınması önem kazanmaktadır. Bu

\section{Ebru ÖZTÜRK}

ÇOPUR ${ }^{1 * \text { iD, }}$

\section{Zehra CAN ${ }^{1}$ (D)}

*Sorumlu Yazar e mail: ebruozturkcapur@kilis.edu.tr

${ }^{1}$ Kilis 7 Aralık Üniversitesi, Yusuf Şerefoğlu Sağllk Bilimleri Fakültesi, Kilis

Öztürk Çopur E, Can Z. Salgın Hastalıkların Kadın Sağlığına Yansımaları. Haliç Üniv Sağ Bil Der. 2021; 87-92

Öztürk Çopur E, Can Z. Reflections of Epidemic Diseases on Women's Health Halic Uni J Health Sci. 2021; $87-92$

Doi: $10.48124 /$

husagbilder.799945

Geliş Tarihi: 25 Eylül 2021 Kabul Tarihi: 6 Ocak 2021 derlemede HIV/AIDS, H1N1, zika virüsü ve koronavirüsler gibi dünyada göze çarpan salgın hastalıkların kadın sağlığına yansımaları incelenecek olup, salgın hastalıklarda kadın sağlığının önemi vurgulanacaktır.

Anahtar Kelimeler; Salgın hastalıklar, kadın, sağlık

\section{REFLECTIONS OF EPIDEMIC DISEASES ON WOMEN'S HEALTH}

\begin{abstract}
Looking from past to present, many epidemic diseases have taken place in the history of the world. Epidemic diseases that affect the world and cause the death of many people are an important public health problem. Among these epidemics, black plague, cholera, Spanish flu, HIV/ AIDS, swine flu (H1N1), zika virus and Covid-19 are the most prominent epidemic diseases. Epidemics affect women and men differently. In women in the risk group, the effects of epidemic diseases on especially pregnant women were seen differently and they could have negative effects on the next generation. Outbreaks, diseases can also affect reproductive and sexual health in various ways. As a result of these, an increase in maternal and neonatal deaths, failure to meet the demands for birth control methods, increase in sexually transmitted diseases and safe abortion, abortion, post-traumatic stress disorder, depression, suicide and violence can be seen. For this reason, it is important handle women separately in epidemic diseases. In our compilation study, the effects of epidemic diseases such as HIV / AIDS, H1N1 (swine flu), zika virus and coronaviruses on women's health will be examined, and the importance of women's health in epidemic diseases will be emphasized.
\end{abstract}

Key Words; Epidemic diseases, women, health 


\section{Giriş}

Salgın hastalık dünyanın farklı bölgelerinde çok hızlı bir yayılım gösterebilen ve tüm dünyayı etkileyen bulaşıcı hastalıklara verilen addır. Biyolojik, çevresel, yaşam tarzı değişiklikleri salgın hastalıkların oluşmasını etkileyen faktörler arasında yer almaktadır (1). Pandemi ise daha çok coğrafi yayılma ile ilgili olup tüm dünyayı etkileyen bir hastalık olarak tanımlanmaktadır (2). Dünya Sağlık Örgütü (DSÖ) hastalıkların pandemi olarak değerlendirilmesinde 3 kriteri temel olarak ele almaktadır. Bunlar; hastalık yapanın yeni bir virüs türü olması, insandan insana, kolayca ve sürekli bulaşabilmesidir (3). Geçmişten günümüze Dünya tarihinde birçok salgın hastalık yer almıştır. Bu salgınlardan kara veba, kolera, İspanyol gribi, HIV/AIDS, domuz gribi (H1N1), zika virüsü ve Covid-19 en göze çarpan salgın hastalıklar olarak karşımıza çıkmaktadır (4).

Dünya'yı etkileyen ve birçok insanın ölümüne yol açan salgın hastalıklar önemli bir halk sağlı̆̆1 problemidir. Birleşmiş Milletler Nüfus Fonu (UNFPA) salgın hastalıkların kadınları ve erkekleri farklı şekilde etkilediklerini belirtmiştir. Ancak çoğu salgın hastalıklarda cinsiyet açısindan analiz yapılmamakta ve cinsiyete dayalı etkiler ele alınmamaktadır. Salgın hastalıkların erkekleri ve kadınları ne kadar etkilediğini bilmek, sağllk durumunun bireyler, cinsiyet, topluluklar üzerindeki birincil ve ikincil etkilerini anlamak için etkili sağlık müdahaleleri ve adil politikalar temel bir adım oluşturur. Geçmişten günümüze kadar yaşanan bu salgın hastalıkların bazılarının kadınlar ve erkekler üzerinde farklı etkileri olmuştur. Risk grubunda olan kadınlarda özellikle de gebelerde salgın hastalıkların etkisi daha farklı görülmüş ve gelecek nesil üzerinde de olumsuz etkiler bırakabilmiştir. Bazı salgın hastalıklarda ise özellikle HIV/AIDS gibi, toplumsal cinsiyet etkilerin kadınların bu salgın hastalıklara daha fazla maruz kalmasını sağlamiştır $(5,6,7)$.

Derleme çalışmamızda HIV/AIDS, H1N1, zika virüsü ve koronavirüsler gibi dünyada göze çarpan salgın hastalıkların kadın sağlığına yansimaları incelenecek olup, salgın hastalıklarda kadın sağlığının önemi vurgulanacaktır.

\section{Salgın Hastalıkların Kadın Sağlığı Açısından Değerlendirilmesi}

Salgın hastalıklar toplumları etkileyen önemli sağlık sorunları arasında yer almaktadır. Salgın hastalıklardan cinsiyet faktörü de etkilenmektedir. Yapılan bazı biyolojik kökenli çalışmalarda salgın hastalıklar ve kıtlık gibi sağlığı etkileyen önemli olaylarda kadınların erkeklerden daha fazla maruz kaldıkları saptanmıştır (8). Yapılan diğer bir çalışma sonucunda ise salgın hastalıklarda potansiyel olarak immünolojik nedenlerden dolayı erkeklerin kadınlardan daha fazla etkilendikleri ortaya çıkmıştır. Ancak hala cinsiyet ile ilgili çalışmalar ve veriler yeterli düzeyde değildir (7). Başka çalışmalarda ise koronavirüslerden olan şiddetli akut solunum yolu sendromu (SARS) ve Orta Doğu solunum sendromu (MERS) salgın hastalığında erkeklerin kadınlardan daha kötü etkilendiği ve ölme riskinin daha yüksek olduğu ortaya çıkmıştır $(9,10)$. Salgın hastalıklarda kadınlar yüksek riskli gruplardan biri olarak kabul edilir. Günümüzde devam eden bir salgın olan Covid-19 salgınında DSÖ, erkeklerin daha fazla öldüğünü ancak kadın sağlığının daha fazla etkilendiğini bildirmiştir. Salgın döneminde gerek sağlık bakım ihtiyacını karşılamada yaşanılan güçlükler ve toplumsal cinsiyet eşitsizliğinin getirdiği yükler nedeniyle kadınların mental sağlık problemleri açısından daha fazla risk altında olmasına neden olmaktadır (11). Salgınlar üreme sağlığı ve cinsel sağlı̆̆ da çeşitli şekillerde etkileyebilmektedir. Bunların sonucunda da anne ve yenidoğan ölümlerinde artış, doğum kontrol yöntemi taleplerinin karş1lanamaması, cinsel yolla bulaşan hastalıkların ve istemli küretajın artması, abortus, travma sonrası stres bozukluğu, depresyon, intihar ve şiddet görülebilmektedir. Salgın hastalıkların fizyolojik etkileri ve toplumsal cinsiyet eşitsizlikleri kadınların salgın hastalıklara daha kolay yakalanmasını sağlamanın yanında kadınların sağlık problemi risklerini arttırmakta aynı zamanda gebelik dönemindeki kadınlarda daha fazla olumsuz etkiler gösterebilmektedir. $\mathrm{Bu}$ sebeple salgın hastalıklarda kadınların ayrı olarak ele alınması önem kazanmaktadır (12). 


\subsection{HIV/AIDS Salgınının Kadın Sağlığına Etkileri}

HIV/AIDS virüsü ilk olarak Dünya'da 1981 yılında ortaya çıkan immun yetmezlik sendromu olarak tanımlanan ve hala günümüzde de devam eden, tedavisi bulunamamış bir salgın hastalık olarak karşımıza çıkmaktadır. HIV virüsü cinsel yolla, kan ve kan ürünler ile anneden bebeğe, tıbbı aletle ve enjektör ile bulaşabilmektedir (13). DSÖ 2019 verileri incelendiğinde dünyada toplam 38 milyon kişide HIV bulunmaktadır. Bunlardan yaklaşık 19,2 milyonu kadınlarda görülürken, 17 milyonu erkeklerde görülmektedir. Elde edilen sonuçları göre dünyada HIV salgınının kadınlarda daha fazla olduğu görülmektedir (14). Kadınlarda HIV virüsünün bu kadar fazla görülmesinde biyolojik etmenlerin yanında toplumsal etkilerinde rolü büyüktür. Bu etmenler arasında toplumsal cinsiyet eşitsizlikleri, kültürel ve cinsel normlar, yoksulluk, eğitim eksikliği yer almaktadır. Aynı zamanda vajinal mikrobiyal ekoloji, hormonal değişiklikler, fizyolojik etmenler ve cinsel yolla bulaşan hastalıkların yüksek prevelansı kadınları HIV virüsüne daha duyarlı hale getirmiştir (15). Yapılan bir çalışmada Rusya ve Ukrayna'daki kadınlarda HIV salgının yayılmasında cinsiyetin önemli bir etkisi olduğu saptanmıştır (16). Dünya çapında kadınlarda daha fazla görülen HIV virüsünün kadın sağlığı üzerinde olumsuz etkileri bulunmaktadır. Özellikle anne ölümlerinde HIV virüsü daha da önem taşımaktadır. Yapılan bir çalışmada HIV virüsü ile enfekte kadınlarda anne ölüm oranının, enfekte olmayan kadınlara göre 10 kat daha fazla olduğu öne sürülmüştür. HIV pozitif kadınlar arasında en yaygın anne ölüm nedenleri arasında AIDS, pnömoni, tüberküloz, menenjit ve gebeliğe bağlı olmayan enfeksiyonlar yer almaktadır. Aynı zamanda HIV pozitif kadınlar, enfekte olmayanlara göre gebelikle ilişkili sepsis ve küretaj komplikasyonlarında ölme riski daha yüksek bulunmuştur $(17,18)$. Yapılan bir çalışmada Institute for Health Metrics and Evaluation (IHME) geliştirdiği bir modelde, dünya çapında anne ölümlerinin \%17,9'unu HIV ile ilişkilendirmiştir (19). HIV emzirmeyi de etkilemektedir. Anneden bebeğe anne sütü ile bulaş olabileceğinden HIV ile enfekte kadınlar bebeklerini emzirememektedir. Bununla birlikte çeşitli ulusal ve uluslararası çalışmalarda kadınlarda emzirememenin duygusal acı, utanç, psikolojik olarak olumsuz etki ve annelik deneyimlerinde zorlama yaşadıkları belirtilmiştir $(20,21)$. HIV virüsünün hala günümüzde tedavisi bulunmasa bile koruyucu ve önleyici yöntemler mümkün olabilmektedir. Özellikle toplumsal cinsiyet eşitsizliğinin kadın üzerindeki olumsuz etkileri nedeniyle kadınlarda daha fazla görülen HIV virüsünde kadınlara yönelik eğitime ve danışmanlık büyük önem kazanmaktadır. Özelikle cinsel yaşam, üreme sağlığ gibi konularda eğitim ve danışmanlık vermek kadınların HIV virüsüne yakalanmamasında önemli bir rol oynamaktadır (22).

\subsection{H1N1 Virüsünün Kadın Sağlığına Etkileri}

Domuz gribi virüsü 2009'da Mart ayında ABD ve Meksika'da ortaya çıkan ve daha sonra birçok ülkeye yayılan bir salgın hastalıktır. Domuz gribi enfekte ettiği kişide üst ve alt solunum yolu enfeksiyonlarına neden olan burun akıntısı, ateş, titreme ve iştahta azalma gibi belirtilere sebep olan bir influenza virüsünün alt tipi olarak tanımlanmaktadır. DSÖ verilerine göre dünyada 204 ülkeye yayılım göstermiştir $(23,24)$. Domuz gribinin de kadın sağlığına yönelik etkileri mevcuttur. Özellikle gebe kadınlar domuz gribi için yüksek riskli gruplar arasında sayılmaktadır. Gebe kadınların domuz gribine gebeliğin geç dönemlerinde yakalanma riskleri daha yüksek bulunmuştur. Domuz gribine yakalanmış gebe kadınların ölüm oranları net olarak belirlenemese de komplikasyon nedeniyle hastaneye yatış oranları dört kat daha fazla bulunmuştur (25). Başka bir çalışmada ise domuz gribinin özellikle gebeliğin ileri dönemlerinde pnömoni, özellikle erken doğum gibi ciddi maternal morbiditeye neden olma potansiyeline sahip olduğu bulunmuştur. Elde elden sonuçlara göre domuz gribi kadınları özellikle de gebeleri olumsuz yönde etkilemektedir $(26,27)$.

\subsection{Zika Virüsünün Kadın Sağlığına Etkileri}

Zika virüsü esas olarak tropikal bölgelerde rastlanan enfekte bir sivrisineğin ısırığı ile bulaşır. Zika virüsü ayrıca hamilelik sırasında cinsel 
temas, kan ve kan ürünlerinin transfüzyonu ve organ nakli yoluyla anneden fetüse bulaşır. Zika virüs enfeksiyonu ile mikrosefali arasında bir ilişki olduğu saptanmıştır. DSÖ verilerine göre zika virüsü toplam 86 ülkeye kadar yayılım göstermiştir. Zika virüsünün henüz bir aşış1 bulunamamıştır (28). Yapılan bir çalışmada zika virüsünden etkilenen gebe kadınların hafif klinik semptomlarına rağmen, fetal ölüm, fetal büyümenin kısıtlanması ve bir dizi merkezi sinir sistemi anomalisi olduğu saptanmıştır (29). Yapılan başka bir çalışmada ise zika virüsüyle ilgili doğum komplikasyonlarının olduğu ve gebe kadınların \%11'inin mikrosefali olan fetüse sahip olduğu saptanmıştır (30). Zika virüsünün gebe kadınlarda oluşturduğu olumsuz etkiler yüzünden kadınlar hem fiziksel hem de psikolojik olarak olumsuz etkilenmektedirler. Zika virüsü olan hamile kadınlara doğum öncesi ve doğum sonrasında mutlaka psikolojik destek sağlanması çok önemlidir $(31,32)$.

\subsection{Koronavirüslerin Kadın Sağlığına Etkileri}

Son yirmi yılda Dünya 3 koronavirüs salgınıyla başa çıkmaya çalışmıştır. Bunlar; 2003 yılında ortaya çıkan SARS-CoV, 2012 yılında ortaya çıkan MERS-CoV, ve 2019 yılında ortaya çıkan Covid-19 salgınlarıdır bu salgınların ortak özellikleri arasında solunum sıkıntısı bulunmaktadır (33). Ortaya çıkan bu koronavirüslerin kadın sağlığı üzerine olumsuz etkileri bulunmaktadır. Yapılan çalışmalarda SARS enfeksiyonun anne ölümü, spontan abortus ile ilişkili olduğu bulunmuştur. Aynı zamanda MERS enfeksiyonda da yeterli veri olmamasına rağmen SARS virüsünde de olduğu gibi ciddi komplikasyonlara yol açacağ düşünülmektedir (34-36). 2019 y1lının son aylarında Çin'in Wuhan kentinde ortaya çıkan, tüm dünyayı etkisi altına alan ve günümüzde de hala varlığını sürdüren Covid-19 virüsü ile ilgili yeterli çalışma olmasa da kadın sağlığı üzerinde etkileri olduğu ortaya çıkmaya başlamıştır. Yapılan bir çalışmada Covid-19 tanısı almış gebe kadınların diğer gebe kadınlara göre yüksek oranda erken doğum riski olduğu ve solunum desteğine ihtiyaç duydukları belirlenmiştir
(37). Yapılan başka bir çalışmada da Covid-19 salgınının kadınların ruh sağlığını olumsuz yönde etkilediği sonucuna varılmıştır (38). Aynı zamanda yapılan başka bir çalışmada da Covid-19 salgınının doğum sonu dönemde kadınların perinatal ruh sağlığını olumsuz yönde etkilediği, depresyon ve anksiyete düzeyinin artmasına sebep olduğu saptanmıştır (39). Covid 19 salgın sürecinde kadınların cinsel sağlık ve üreme sağlığı konusunda da sıkıntı yaşayabilmektedir. Salgınla birlikte milyonlarca kadının aile planlaması alamama riski ortaya çıkmakta ve istenmeyen gebelik, güvenli olmayan düşük, cinsel yolla bulaşan enfeksiyonlar, anne ve bebek ölümlerinde artış riski bulunmaktadır. Hala devam eden Covid-19 salgınının kadın sağlığına etkilerine yönelik yeterli veri bulunmamakla birlikte bazı riskleri de beraberinde getirmektedir. Covid-19'un bir salgın olması nedeniyle fiziksel, psikolojik ve sosyal yönden kadın sağlığına olumsuz etkileri mevcuttur (40).

\section{Sonuç ve Öneriler}

Sonuç olarak; salgın hastalıkların kadın sağlığına her yönüyle olumsuz etkileri mevcuttur. Salgın hastalıklarda biyolojik olarak erkeklerin daha fazla etkilendiği belirtilse de her yönü ile ele alındığında mental olarak kadınların daha fazla ve uzun süreli etkilendiği ortaya çıkmıştır. Ortaya çıkan salgın hastalıklarda kadınlarda cinsel ve üreme sağlığ 1 problemlerinin ortaya çıkma riski artmakta, aile planlaması olumsuz etkilenmekte ve toplumsal cinsiyet eşitsizliğine yönelik problemler ortaya çıkmaktadır. $\mathrm{Bu}$ bağlamda salgın hastalıklarda kadın sağlığını korumaya yönelik öncelikli müdahaleler;

- Kadınların cinsel sağlık ve üreme sağlığ1 hizmetlerinin ve müdahalelerinin korunmasını sağlamak,

- Modern gebelik önleyici araçları ve diğer üreme sağlığı ürünlerinin tedarikini sağlayarak aile planlamasını korumak,

- Toplumsal cinsiyet eşitsizliğine yönelik çalışmalar sürdürmek şeklinde olmalıdır.

Unutulmamalıdır ki kadın sağlığını korumak aslında toplumun sağlığını korumaktır. 


\section{Kaynakça}

1. World Health Organization. Managing epidemics: key facts about major deadly diseases. World Health Organization, 2018.

2. Samal J. A historical exploration of pandemics of some selected diseases in the world. International Journal of Health Sciences and Research; 2014; 4(2): 165-169.

3. BBC News Türkçe. Pandemi nedir, ülkeleri nasıl etkiler? - Dünya Sağlık Örgütü koronavirüs pandemi ilan etti [Internet]. Erişim Tarihi:27.08.2020. Erişim Adresi: https://www. bbc.com/turkce/haberler-dunya 51614548.

4. Eşidir VO, Bak G. Geçmişten günümüze İspanyol Gribi 'ne Türkiye'den bakış. Ankara. Iksad Publications; 2020.

5. Can, HB. Olağanüstü durumlarda geliştirilen sosyal politikaların dezavantajlı gruplar üzerindeki etkisinin sosyal hizmet perspektifinden değerlendirilmesi: Covid-19 pandemisi Türkiye örneği. Sosyal Hizmet, 2020; 47.

6. Richardson ET, Collins SE, Kung T, Jones HJ, Tram KH, Boggiano VL, Bekker LG, Andrew ZR. Gender inequality and HIV transmission: A global analysis. Journal Of The International AIDS Society; 2014;17.1: 19035.

7. Yildırım C. Covıd-19: Cinsiyet bağlamında değerlendirme. Sosyal Hizmet, 2020; 94.

8. Zarulli V, Jones, JAB, Oksuzyan A, Lindahl-Jacobsen R, Christensen K, Vaupel JW. Women live longer than men even during severe famines and epidemics. Proceedings of the National Academy of Sciences; 2018; 115(4): E832-E840.

9. Karlberg J, Chong DSY, Lai WYY. Do men have a higher case fatality rate of severe a cute respiratory syndrome than women do?. American journal of epidemiology; 2004; 159(3): 229-231.

10. Chen X, Chughtai AA, Dyda A, MacIntyre CR. Comparative epidemiology of Middle East respiratory syndrome coronavirus (MERS-CoV) in Saudi Arabiaand South Korea. Emerging Microbes \& İnections; 2017 6(1): 1-6.

11. Evcili F, Demirel G. Covid-19 pandemisinin kadın sağlığına etkileri ve öneriler üzerine bir değerlendirme. Türk Fen ve Sağlık Dergisi; 2020; 1(2): 1-2.

12. Yağmur Y. 3. Ünite: COVID-19'un kadın sağlığı üzerine etkileri. Yeni koronavirüs hastalığ1nın toplum üzerine etkileri. Malatya. İnönü Üniversitesi Yayınevi; 2020; (27).
13. Tümer A, Ünal S. HIV/AIDS epidemiyolojisi ve korunma. Sosyal Politika Çalışmaları Dergisi; 2016; 4(4).

14. World Health Organization. Summary of the global HIV epidemic, 2019 [Internet]. Erişim Tarihi: 27.08.2020. Erişim Adresi: https://www. who.int/hiv/data/2019_summary-global-hiv-epi. png.

15. Quinn TC, Overbaugh J. HIV/AIDS in women: an expanding epidemic. Science; 2005; 308(5728): 1582-1583.

16. Burruano L, Yury K. "HIV/AIDS epidemic in Eastern Europe: recent developments in the Russian Federation and Ukraine among women." Gender Medicine; 2009;6(1): 277-289.

17. Moran NF, Moodley J. The effect of HIV infection on maternal health and mortality. International Journal of Gynecology \& Obstetrics; 2012; 119: S26-S29.

18. McIntyre J. "Mothers infected with HIV: reducing maternal death and disability during pregnancy. British Medical Bulletin; 2003; 67(1): 127-135.

19. Calvert C, Ronsmans C. The contribution of HIV to pregnancy-related mortality: a systematic review and meta-analysis. AIDS; 2013;27(10):1631-1639.

20. Miottı PG, Taha ET, Kumwenda et al. HIV transmission through breastfeeding: a study in Malawi. Jama;1999; 282 (8): 744-749.

21. Alvarenga WA, Nascimento LC, Leal CL, Fabbro MRC, Bussodori JCC, Melo SSS, Ramod DC, Dupas G. Mothers living with HIV: replacing breastfeeding by infant formula. Revista Brasileira De Enfermagem; 2019; 72 (5): 1153-1160.

22. Gupta G. Globalization, women and the HIV/ AIDS epidemic. Peace Review; 2004; 16(1): 7983.

23. Jilani TN, Jamil RT, Siddiqui AH. H1N1 Influenza (Swine Flu) [Updated 2020 Jul 20]. In: StatPearls [Internet]. 2020, Treasure Island (FL): StatPearls Publishing.

24. Çalım T, İldan S. Üniversite Ögrencilerinin Domuz Gribi Ve Aşısı Hakkında Düşünceleri. Anatolian Journal of Clinical Investigation; 2011; $5(3)$.

25. Toal, M, Agyeman-Duah K, Schwenk A, Yoong W. Swine flu and pregnancy. Journal of Obstetrics and Gynaecology; 2010; 30(2): 97-100.

26. Michaan N, Amzallag S, Laskov I, Cohen Y, Fried M, Lessing JB, Many A. Maternal and 
neonatal outcome of pregnant women infected with H1N1 influenza virus (swine flu). The Journal of Maternal-Fetal \& Neonatal Medicine; 2012; 25(2): 130-132.

27. Yates L, Pierce M, Stephens S, Mill AC, Spark P, Kurinczuk JJ, Valappil M, Brocklehurst M, Thomas SHL, Knight M. Influenza A/H1N1v in pregnancy: an investigation of the characteristics and management of affected women and the relationship to pregnancy outcomes for mother and infant. Health Technol Assess; 2010; 14(34), 109-82.

28. World Health Organization. Zika virus disease [Internet]. Erişim Tarihi: 27.08.2020. Erişim Adresi: https:/www.who.int/health-topics/zika-virus-disease\#tab=tab_1.

29. Brasil P, Pereira Jr JP., Moreira ME, Ribeiro Nogueira RM, Damasceno L, Wakimoto M, Zin AA, et al. Zika virus infection in pregnant women in Rio de Janeiro. New England Journal of Medicine; 2016; 375(24): 2321-2334.

30. Honein MA, Dawson AL, Petersen EE, Jones AM, Lee EH, Yazdy MM, Ellington SR. Birth defects among fetuses and infants of US women with evidence of possible Zika virus infection during pregnancy. Jama; 2017; 317(1): 59-68.

31. Dinız D. Zika virus and women. Cad. Saúde Pública; 2016; 32 (5).

32. Duarte G, Moron AF, Timerman A, Fernandes CE, Mariani Neto C, Almeida Filho GLD, Andrade JBBD. Zika virus infection in pregnant women and microcephaly. Revista Brasileira de Ginecologia e Obstetrícia; 2017; 39(5): 235-248.

33. Guarner J. Three emerging corona viruses in two decades: the story of SARS, MERS, and now
COVID-19. American Journal of Clinical Pathology; 2020; 153(4): 420-421.

34. Wong SF, Chow KM, Leung TN, Ng WF. Ng, TK., Shek CC, Lai ST. Pregnancy and perinatal outcomes of women with severe acute respiratory syndrome. American Journal Of Obstetrics And Gynecology; 2004;191(1), 292-297.

35. Wong SF, Chow, KM, De Sw1et M. Severe a cute respiratory syndrome and pregnancy. Bjog;2003; 110(7): 641.

36. Swartz D, Graham A. Potential maternal and infant outcomes from coronavirus 2019-nCoV (SARS-CoV-2) infecting pregnant women: Lessons from SARS, MERS, and Other Human Coronavirus Infections. Viruses; 2020; 12(2): 194.

37. London V, McLaren Jr R, Atallah F, Cepeda C, McCalla S, Fisher N, Minkoff H. The relationship between status at presentation and outcomes among pregnant women with COVID-19. American journal of perinatology; 2020; 37(10): 991.

38. Davenport MH, Meyer S, Meah VL, Strynadka MC, Khurana R. Moms are not ok: COVID-19 and maternal mental health. Frontiers in Global Women's Health; 2020; Womens Health; 1(1).

39. Ceulemans M, Hompes T, Foulon V. Mental health status of pregnant and breastfeeding women during the COVID-19 pandemic: A call for action. International Journal of Gynecology \& Obstetrics; 2020; 1(2).

40. Aylaz R, Yıldız E. Yeni koronavirüs hastalığının toplum üzerine etkileri ve hemşirelik yaklaşımları. Malatya. İnönü Üniversitesi Yayınevi, 2020. 